\title{
The Prevalence of Depression, Anxiety, Stress and Its Association with Sleep Quality among Medical Students
}

\section{Tıp Fakülttesi Öğrencilerinde Depresyon, Anksiyete, Stres Prevalansı ve Uyku Kalitesi ile İlișkisi}

\author{
İlkay Doğan' ${ }^{1}$ Nurhan Doğan ${ }^{2}$ \\ ${ }^{1}$ Gaziantep Üniversitesi, Tıp Fakültesi, Biyoistatistik Anabilim Dalı \\ ${ }^{2}$ Afyonkarahisar Sağlık Bilimleri Üniversitesi, Tıp Fakültesi, Biyoistatistik Anabilim Dalı
}

\begin{abstract}
Objectives: Currently, depression, anxiety, and stress among medical students are important health issues at global level. The aim of this study was to assess the prevalence of depression, anxiety, stress among medical students, and its association with socio-demographic characteristics and sleep quality.

Materials and Methods: DASS-42 Scale and Richard Campbell Sleep Questionnaire were used to assess information on depression, anxiety, stress, and sleep quality. A total of 610 students $(44.10 \%$ males and $55.90 \%$ females) with mean age of $20.90 \pm 2.10$ years participated in the present study.

Results: The overall prevalence of depression, anxiety, and stress were $60 \%, 66 \%$, and $63 \%$ among all participated medical students, respectively. Depression level was high among students with poor economic level. Anxiety level was high among pre-clinical students with poor economic level, females and the ones whose choice of the medical faculties was not voluntarily. Stress level was higher in females. The correlation between sleep quality and depression, anxiety, stress was found statistically significant, negative, and low level. High depression, anxiety, and stress levels decreased students' sleep quality.

Conclusion: An important proportion of medical students had high levels of depression, anxiety, and stress. Providing individual guidance and psychological counseling services for medical students could be beneficial.
\end{abstract}

Keywords: Depression, anxiety, stress, sleep quality, medical students

$\ddot{O} \mathbf{z}$

Amaç: Günümüzde tıp öğrencileri arasında depresyon, anksiyete ve stres küresel seviyede önemli bir sağlık sorunudur. Bu çalışma ile tıp fakültesi öğrencilerinde depresyon, anksiyete ve stres prevalansının araștırılması ve bunların uyku kalitesi ve demografik özellikler ile ilişkisini değerlendirmek amaçlanmıştır.

Materyal ve Metot: Depresyon, anksiyete, stres ve uyku kalitesi hakkındaki bilgileri değerlendirmek

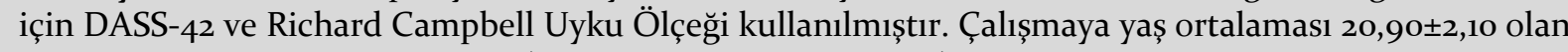
toplam 6ıo tıp fakültesi öğrencisi (44,10\% erkek ve 55,90\% kız) katılmıștır.

Bulgular: Çalışmaya katılan tıp öğrencilerinde depresyon, anksiyete ve stres prevalansı sırasıyla $60 \%$, $66 \%$, ve $63 \%$ olarak belirlenmiștir. Depresyon düzeyi, ekonomik düzeyi öğrencilerin yüksektir. Anksiyete düzeyi, klinik öncesi öğrencilerde, kızlarda ve tıp fakültesini kendi isteği ile tercih etmeyen öğrencilerde yüksektir. Stres düzeyi ise kızlarda yüksektir. Uyku kalitesi ile depresyon, anksiyete ve stres arasındaki ilişki istatistiksel olarak anlamlı, negatif yönde ve düșük seviyede bulunmuştur. Yüksek depresyon, anksiyete ve stres düzeyi öğrencilerin uyku kalitesini azaltmaktadır.

Sonuç: Tıp öğrencilerinin önemli bir kısmında yüksek düzeyde depresyon, anksiyete ve stres belirlenmiștir. Tıp öğrencileri için bireysel rehberlik ve psikolojik danışma hizmetleri verilmesinin yararlı olabileceği düşünülmektedir.

Anahtar Kelimeler: Depresyon, anksiyete, stres, uyku kalitesi, tıp öğrencileri

\section{Yazıșma Adresi / Correspondence:}

İlkay Doğan

Gaziantep Üniversitesi Tıp Fakültesi Biyoistatistik Anabilim Dalı, Gaziantep

e-mail: ilkay_dgn58@hotmail.com

Date of Admission: 19.03.2019

Date of Submission: 28.08.2019 
The Prevalence of Depression, Anxiety, Stress and Its Association with Sleep Quality among Medical Students

\section{Introduction}

Currently, depression, anxiety and stress among medical students are an important health issues at the global level. Medical students must acquire sufficient vocational knowledge, skills, and attitudes to prepare themselves to cope with life-long professional difficulties. However, learning and educational demands can affect the physical and mental health of the students in a negative way. This situation leads to depression, anxiety, and stress in the life of medical students, and they tend to have more psychological distress compared to the general population. ${ }^{1,2}$

Depression, anxiety, and stress formation among medical students can be multifactorial. These factors are classified as academic and non-academic (psychosocial and socio-demographic) stress factors.3,4 These factors include comprehensive medical curriculum, long course hours, concerns about academic performance, high family expectations and socio-demographic characteristics. These stress factors may lead to depression, anxiety, stress, poor sleep quality, low academic performance, alcohol and drug abuse, loss of self-confidence, poor life quality, and psychiatric illnesses. ${ }^{5-8}$

In a society, university students are the most dynamic element of society's sociocultural structure. It was stated that depression is the most important psychological distress that threatens this group in researches among university students.9,10 Psychological distress prevalence (depression, anxiety, stress) among medical students has been varied in different studies and countries. The prevalence of depression has changed in various societies such as Sweden 12.90\%; Iran 51\%; Denmark 30.50\%; Cameroon $65.2 \% .^{8,11,12}$ Similarly, it is stated that the prevalence of anxiety in various societies (e.g. Pakistan 13\%; Estonia 21.90\%; Malesia 76.20\% etc.) has changed between $13 \%$ and $76.20 \% .{ }^{13-15}$ The high prevalence of stress is one of the most important problems among medical students worldwide. For instance, different societies such as Nepal 27\%; Malaysia 46.90\%; Sudan 50,50\%; Iran 72.30\% indicated different stress levels. ${ }^{4,6,7,11,16}$ Studies carried out in the medical faculty and other faculties in Turkey have showed that the prevalence of depression, anxiety and stress changed between 27.10\%-73.50\%; 17.90\%-55.40\%; 27\%-46.40\%; respectively.5,17-23 Many studies have reported that levels of depression, anxiety, and stress have been increased in recent years. Stress leads to some problems such as anxiety, depression, sleep disorders, coronary heart diseases, psychosomatic diseases, weakness of the immune system, and cancer. ${ }^{6}$

In accordance with this information, the purpose of the present study was to investigate the prevalence of depression, anxiety, and stress among medical students in Afyonkarahisar Health Sciences University, and its association with socio-demographic characteristics and sleep quality. The hypotheses of study are given below:

- What is the prevalence of depression, anxiety and stress among medical students at Afyonkarahisar Health Sciences University?

- Is there any association between socio-demographic characteristics and depression, anxiety, and stress?

- Is there a correlation between sleep quality and depression, anxiety, and stress? 


\section{Materials and Methods}

The sample of the study consisted of a total of 610 ( 341 female and 269 male) medical students. A questionnaire form consisting of totally three parts was used in the study: Depression, Anxiety and Stress Scale (DASS-42), Richard-Campbell Sleep Quality Questionnaire, and personal information form (age, gender, sleep hours, fluid consumption, etc.). DASS-42 is a scale developed by Lovibond, P. and Lovibond, $\mathrm{S}^{24}$ to determine individual's levels of depression, anxiety, and stress. The scale consists of totally 42 items including three dimensions with 14 items about depression, 14 items about anxiety, and 14 item about stress. Depression items measure dissatisfaction, despair and worthlessness, loss of interest, and low energy levels. Anxiety items assess the individual's autonomic arousal, situational anxiety, subjective anxiety, and muscle response level. Stress items measure the level of symptoms of relaxation difficulty, nervous stimulation, quick worry and press, discomfort, overreaction, and intolerance. The validity and reliability of DASS-42 scale were performed by Akin and Çetin ${ }^{19}$ and Bayram and Bilgel ${ }^{25}$ in Turkey.

Richard-Campbell Sleep Questionnaire developed by Richards ${ }^{26}$ evaluates the depth of night sleep, the dozing off time, the frequency of waking, the duration of awake at night, sleep quality, and noise level in the environment. This scale consists of six items. The validity and reliability of scale were performed by Özlü and Özer ${ }^{27}$ in Turkey.

A cross-sectional study was designed as a research method. Pearson correlation analysis was used to determine the relation between depression, anxiety, stress, and sleep quality. Independent sample t test was used to compare depression, anxiety, and stress level according to class (clinical class/pre-clinical class). Moreover, the important risk factors (socio-demographic characters and sleep quality) for depression, anxiety, and stress were determined using binary logistic regression analysis. SPSS software program was used for data analysis. The study was conducted in accordance with the ethical approval with the protocol number of 2017/11-261 from the Faculty of Medicine, Afyon Kocatepe University.

\section{Results}

A total of 610 students (44.10\% males, $55.90 \%$ females) with the mean age of $20.90 \pm 2.10$ years (21.23 \pm 2.29 males, 20.79 \pm 1.92 females) at Afyonkarahisar Health Sciences University Faculty of Medicine voluntarily participated. The mean and standard deviation score of depression, anxiety, and stress were $13.93 \pm 5.51 ; 11.55 \pm 7.42 ; 17.79 \pm 8.37$ for all participants, respectively. When the scores were classified, 60.20\%, 66.20\%, $62.60 \%$ of the participants had depression, anxiety, and stress symptoms, respectively. (Table 1).

The difference between depression, anxiety, and stress levels according to the class of students was summarized in Table 2 and Figure 1. Anxiety level was statistically different according to the class of the students ( $<<0.05)$. Anxiety level in pre-clinical classes was higher than clinical classes. Depression and stress level were not statistically different according to the classes ( $p>0.05)$. As a result, depression and stress level did not change according to the class, and students had same depression and stress level (high level) in all classes (Table 2). Depression, anxiety, and stress levels of the students at second grade were higher than the other classes (Figure 1). 
The Prevalence of Depression, Anxiety, Stress and Its Association with Sleep Quality among Medical Students

Table 1. Depression, anxiety, and stress levels of participants

\begin{tabular}{|c|c|c|c|}
\hline & $\begin{array}{c}\text { Depression } \\
\text { n }(\%)\end{array}$ & $\begin{array}{c}\text { Anxiety } \\
\mathrm{n}(\%)\end{array}$ & $\begin{array}{l}\text { Stress } \\
\mathrm{n}(\%)\end{array}$ \\
\hline Normal & $243(39.80)$ & $206(33.80)$ & $228(37.40)$ \\
\hline Abnormal & $367(60.20)$ & $404(66.20)$ & $382(62.60)$ \\
\hline Slight & $86(14.10)$ & $67(11.00)$ & $117(19.20)$ \\
\hline Middle & $131(21.50)$ & $150(24.50)$ & $150(24.60)$ \\
\hline High & $91(14.90)$ & $92(15.10)$ & $89(14.50)$ \\
\hline Very High & $59(9.70)$ & $95(15.60)$ & $26(4.30)$ \\
\hline
\end{tabular}

Table 2. Comparison of depression, anxiety and stress levels according to classes

\begin{tabular}{|c|c|c|c|c|c|}
\hline Variables & Classes & $\mathbf{N}$ & Mean \pm Standard Deviation & $t$ & $p$ \\
\hline \multirow{2}{*}{ Depression } & Preclinical classes & 348 & $14.53 \pm 9.23$ & \multirow{2}{*}{1.825} & \multirow{2}{*}{0.069} \\
\hline & Clinical classes & 262 & $13.12 \pm 9.82$ & & \\
\hline \multirow{2}{*}{ Anxiety } & Preclinical classes & 348 & $12.27 \pm 7.49$ & \multirow{2}{*}{2.783} & \multirow{2}{*}{$0.006^{*}$} \\
\hline & Clinical classes & 262 & $10.59 \pm 7.22$ & & \\
\hline \multirow{2}{*}{ Stress } & Preclinical classes & 348 & $18.23 \pm 8.31$ & \multirow{2}{*}{1.482} & \multirow[b]{2}{*}{0.139} \\
\hline & Clinical classes & 262 & $17.21 \pm 8.42$ & & \\
\hline
\end{tabular}

${ }^{*} p<0.05$

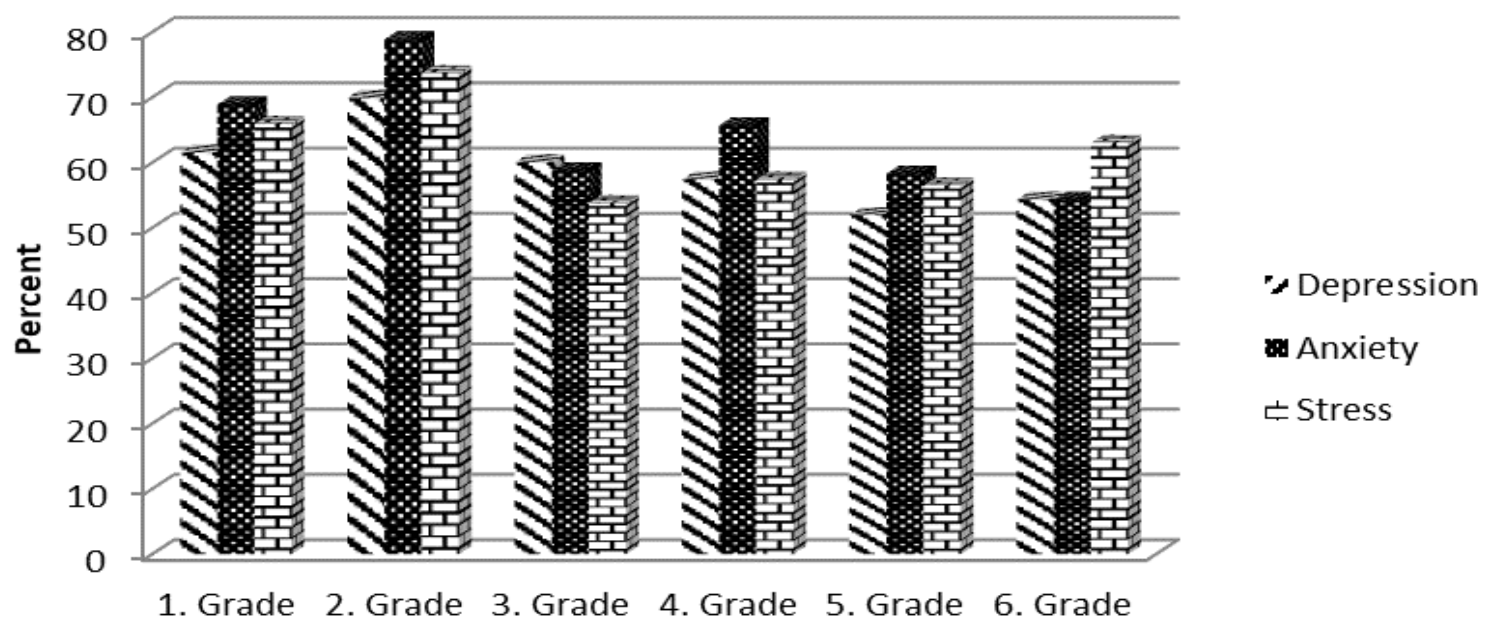

Classes

Fig. 1. Depression, anxiety and stress levels of students according to classes

Binary logistic regression analysis was used to evaluate the effects of sociodemographic characteristics of students on depression, anxiety, and stress. While the students with normal depression, anxiety, and stress were coded as "o", the students 
The Prevalence of Depression, Anxiety, Stress and Its Association with Sleep Quality among Medical Students

with slight, middle, high or very high depression, anxiety, and stress were coded as "1". The results of binary logistic regression analysis were shown in Table 3 .

Table 3. The risk factors for depression, anxiety, and stress

\begin{tabular}{|c|c|c|c|c|c|c|}
\hline \multirow{2}{*}{\multicolumn{2}{|c|}{ Socio- demographic characters }} & \multirow{2}{*}{$\begin{array}{c}\text { B } \\
-0.593 \\
-0.185\end{array}$} & \multirow{2}{*}{$\begin{array}{c}\mathrm{p} \\
0.064\end{array}$} & \multirow{2}{*}{$\begin{array}{l}\text { Exp } \\
\text { (B) }\end{array}$} & \multicolumn{2}{|c|}{ \% 95 CI $\operatorname{Exp}(B)$} \\
\hline & & & & & $\begin{array}{l}\text { Lower } \\
\text { bound }\end{array}$ & $\begin{array}{l}\text { Upper } \\
\text { bound }\end{array}$ \\
\hline Depression & $\begin{array}{l}\text { Economic level } \\
\text { Middle } \\
\text { Good } \\
\text { Waking time in the } \\
\text { morning } \\
\text { o6:00-06:59 } \\
\text { After 07:00 } \\
\text { Energy substance (No) } \\
\text { Study duration during an } \\
\text { exam period } \\
\text { 3-4 hours } \\
\text { More than } 5 \text { hours } \\
\text { Anxiety (Abnormal) } \\
\text { Stress (Abnormal) }\end{array}$ & $\begin{array}{l} \\
-0.593 \\
-0.185 \\
0.171 \\
0.835 \\
-1.012\end{array}$ & $\begin{array}{c}0.064 \\
0.043 \\
0.566 \\
0.021 \\
0.486 \\
0.008 \\
0.003 \\
0.013 \\
\\
0.344 \\
0.015 \\
<0.001 \\
<0.001\end{array}$ & $\begin{array}{l}0.552 \\
0.831 \\
\\
1.186 \\
2.304 \\
0.364\end{array}$ & $\begin{array}{c}0.311 \\
0.442 \\
\\
0.734 \\
1.245 \\
0.186\end{array}$ & $\begin{array}{l}0.983 \\
1.564 \\
\\
1.919 \\
4.266 \\
0.710\end{array}$ \\
\hline Anxiety & $\begin{array}{l}\text { Gender (Woman) } \\
\text { Economic Level } \\
\text { Middle } \\
\text { Good } \\
\text { Education level of the } \\
\text { father } \\
\text { High school } \\
\text { University, master, } \\
\text { Ph.D. } \\
\text { Smoking } \\
\text { Smoking before } \\
\text { Still smoking } \\
\text { Choosing the medical } \\
\text { faculties whether } \\
\text { voluntarily (No) } \\
\text { Sleep Quality (Very high) } \\
\text { Stress (Abnormal) } \\
\text { Depression (Abnormal) } \\
\end{array}$ & $\begin{array}{c}0.539 \\
- \\
0.829 \\
-0.757 \\
\\
-0.750 \\
- \\
0.769 \\
\\
0.942 \\
0.073 \\
0.575 \\
\\
-0.397 \\
1.732 \\
1.488\end{array}$ & $\begin{array}{c}0.013 \\
0.022 \\
0.006 \\
0.037 \\
0.057 \\
0.028 \\
0.025 \\
0.085 \\
0.026 \\
0.815 \\
0.098 \\
\\
0.067 \\
<0.001 \\
<0.001\end{array}$ & $\begin{array}{l}1.714 \\
0.436 \\
0.469 \\
0.472 \\
0.463 \\
\\
2.566 \\
1.076 \\
1.777 \\
\\
0.672 \\
5.654 \\
4.428\end{array}$ & $\begin{array}{c}1.120 \\
0.242 \\
0.230 \\
0.241 \\
0.237 \\
\\
1.117 \\
0.584 \\
0.899 \\
\\
0.439 \\
3.593 \\
2.833\end{array}$ & $\begin{array}{l}2.623 \\
\\
0.787 \\
0.955 \\
\\
0.924 \\
0.907 \\
\\
5.896 \\
1.982 \\
3.510 \\
\\
1.028 \\
8.896 \\
6.922\end{array}$ \\
\hline Stress & $\begin{array}{l}\text { Gender (Woman) } \\
\text { Sleep Quality (Very high) } \\
\text { Working status of father } \\
\quad \text { Retired } \\
\text { Working } \\
\text { Anxiety (Abnormal) } \\
\text { Depression (Abnormal) }\end{array}$ & $\begin{array}{c}0.422 \\
- \\
0.399 \\
-1.780 \\
-1.534 \\
1.543 \\
1.978 \\
\end{array}$ & $\begin{array}{l}0.054 \\
0.070 \\
<0.001 \\
<0.001 \\
<0.001 \\
<0.001\end{array}$ & $\begin{array}{l}1.524 \\
0.671 \\
\\
0.169 \\
0.216 \\
4.679 \\
7.229\end{array}$ & $\begin{array}{l}0.993 \\
0.436 \\
\\
0.093 \\
0.135 \\
3.027 \\
4.714\end{array}$ & $\begin{array}{r}2.339 \\
1.033 \\
0.306 \\
0.345 \\
7.232 \\
11.086\end{array}$ \\
\hline
\end{tabular}

References: Economic level=poor; Waking time in the morning= before o6:oo; Energy substance=Yes; Study duration during an exam period: less than 3 hours; Anxiety=Normal; Stress=Normal, Depression=Normal; Gender=Man; Education level of the father=primary school; Smoking=Never smoking; Choosing the medical faculties voluntarily=Yes; Sleep quality=poor; Working status of father= not working; $\mathrm{CI}$ : confidence interval; $\mathrm{p}<0.05$. 
The economic level of family, waking time in the morning, the use of energy substances (beverage, medicine, etc.), study duration during exam period, anxiety, and stress were identified as risk factors for depression. The middle economic level of family, the use of energy substances, and the length of study during exam periods reduced the risk of depression 1.80 times, 2.70 times, and 2.30 times, respectively. On the other hand, waking up after 7:00, anxiety, and stress increased the risk of depression 2.30 times, 3.90 times, and 7.80 times, respectively (Table 3).

The economic level of the family, gender, education level of the father, smoking, voluntary or involuntary choice of the medical faculties, sleep quality, stress, and depression were identified as risk factors for anxiety. The good economic level of family, high education level of the father, and high sleep quality reduced the anxiety risk 2.10 times, average 2 times, and 1.50 times, respectively. On the other hand, being a woman, smoking, involuntary choice of the medical faculties, depression, and stress increased the anxiety risk 1.70 times, average 2 times, 1.80 times, 4.40 times, and 5.70 times, respectively (Table 3 ).

Gender, whether the father had a job, sleep quality, anxiety, and depression were identified as important risk factors for stress. Having a good sleep quality and having a working father reduced the stress risk 1.50 times, and 4.60 times, respectively. On the other hand, being a woman, depression, and anxiety increased the stress risk 1.50 times, 7.20 times, and 4.70 times, respectively.

Table 4 showed that the results of the correlation analysis between depression, anxiety, stress, and sleep quality. The correlation between sleep quality and depression, anxiety, stress was found statistically significant, negative, and low level $(\mathrm{p}<0.05)$. It was found that the medical students having high depression, anxiety, and stress levels had sleeping problems (unable to start sleep or unable to continue sleep) and low sleep quality (Table 4).

Table 4. The relationship between depression, anxiety, stress and sleep quality

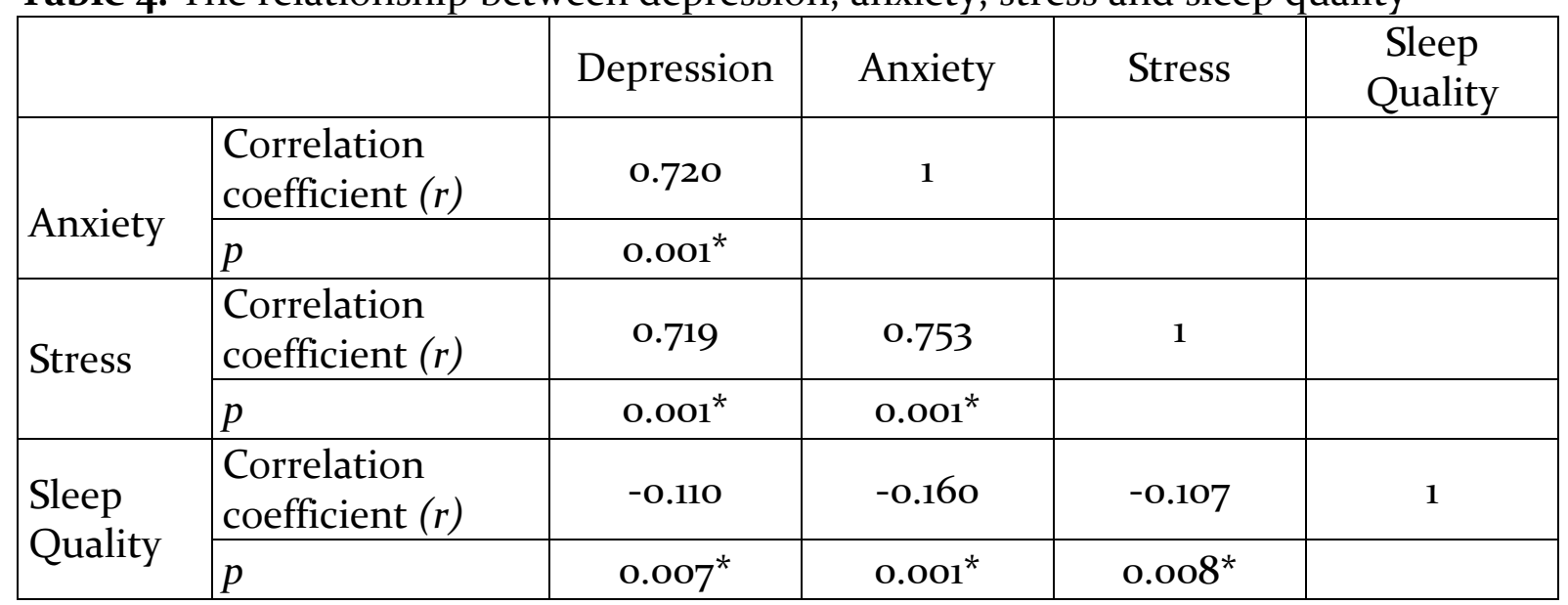

${ }^{*} p<0.05$

\section{Discussion}

Depression, anxiety, and stress are the most common psychiatric disorders in the society. Depression among medical students is a worldwide phenomenon. Despite major changes in medical education, depression remains a major problem. In this 
context, depression $(60.20 \%)$, anxiety $(66.20 \%)$, and stress $(62.60 \%)$ prevalence were common among the students of the Medicine Faculty of Afyonkarahisar Health Sciences University (Table 1). These results showed that the prevalence of depression, anxiety, and stress is higher than the previous studies in Turkey. $., 17-23,28$

Results of depression prevalence obtained from the present study were similar with the results obtained in some other countries: Cameroon $65.20 \%{ }^{29}$, Pakistan $51 \%^{14}$, Syria $60.60 \% \%^{4}$, Sudan $53.40 \% \%^{16}$, Malesia $60.20 \% \%^{13}$, Egypt $57.90 \%{ }^{30}$ and $65^{3{ }^{11}}$, Iran $51 \%^{11}$, and India $51.30 \%{ }^{3}$. Countries with lower prevalence of depression were Sweden $12.90 \% \%^{8}$, Denmark 30.50\% $\%^{12}$, Estonia 30.60\% $\%^{15}$, Nepal 29.90\% $\%^{32}$ and 33\%33, and Saudi Arabia $43 \%^{1}$. Results of depression prevalence seem to be closer and higher to each other among the Middle Eastern countries.

Results of anxiety prevalence obtained from the present study were similar with the results obtained in some other countries: Sudan $5_{1} \% \%^{16}$, Egypt $57.90 \%{ }^{30}$ and $73 \%{ }^{31}$, Saudi Arabia $63 \%{ }^{1}$, India $66.90 \%{ }^{3}$, and Malesia $76.20 \%{ }^{13}$. Countries with lower prevalence of anxiety were Pakistan $13 \% 0^{14}$, Estonia $21.90 \%{ }^{15}$, Syria $35.10 \%{ }^{4}$, Nepal $41.10 \% 3^{32}$, and Iran $40.30 \%{ }^{11}$. Results of anxiety prevalence seem to be closer and higher to each other among the East Asian and Arabian countries.

Results of stress prevalence obtained from the present study were similar some countries: Iran $72.30 \%^{11}$, Egypt $59.90 \% \%^{31}$, Ethiopia $52.40 \%^{7}$ and $53.20 \%^{6}$, Syria $52.60 \%{ }^{4}$, Sudan $50.50 \%{ }^{16}$, and India $53 \%{ }^{3}$. Countries with lower prevalence of anxiety were Malaysia $46.90 \%{ }^{13}$, Saudi Arabia $41 \%^{1}$, and Nepal $27 \%^{32}$. Because students are exposed to too much stress in addition to the normal stress factors of daily life, the prevalence of stress is high nearly in all countries. Comprehensive medical curriculum, long course hours, concerns about academic performance, high family expectations, and socio-demographic characteristics are some of these stress factors.

Depression, anxiety, and stress levels were higher in second-grade students than in other grades (Table 2; Figure 1). In the literature, some other research studies emphasized the same result. ${ }^{2,4,5,8,14,16}$ In contrast, Ediz et al. ${ }^{24}$ found first grade students had a high depression, anxiety, and stress level. Also, Bayram and Bilgel ${ }^{13}$ and Fuad et al. ${ }^{19}$ indicated that pre-clinical students (first grade and second grade) had a high depression, anxiety, and stress level. It can be explained by the usual stress of the first and second-grade students who are newly acquainted with the academic environment. Moreover, Bassols et al. ${ }^{34}$ indicated that sixth grade students had a lower depression, anxiety, and stress level than other grades. It can be explained by the fact that the sixth-grade students adapt to academic standing and do not have to take an exam.

According to the results of binary logistic regression (Table 3), the poor economic level of the family, the use of energy substances, the short study duration during an exam period, anxiety, and stress increased the risk of depression. Being a woman, poor economic level of the family, low educational level of the father, the involuntary choice of medical faculties, poor sleep quality, stress and depression increased the anxiety risk. Being a woman, an unemployed father, poor sleep quality, anxiety, and depression increased the risk of stress. Similar risk factors for depression, anxiety, and stress were obtained from the related literature. $4,7,13,17,23$

It was found that statistically significant, negative, and low-level correlation between sleep quality and depression, anxiety, stress. Sleep quality was found to be low in students with high levels of depression, anxiety, and stress (Table 4). Najafi Kalyani et 
al. ${ }^{6}$ and Almojali et al. ${ }^{11}$ also indicated that students with high levels of depression, anxiety, and stress had a low sleep quality.

The results of this study were closer to the results of the studies conducted in the Middle Eastern, Asian, and Arabian countries. The prevalence of depression, anxiety, and stress among medical students in these countries has been generally higher than the ones in the European countries. High depression, anxiety, and stress levels may be due to cultural and religious differences between the Eastern and Western countries. Consequently, depression, anxiety, and stress levels were found to be high at the students of Medical Faculty of Afyonkarahisar Health Sciences University. Students with these problems need to be identified and it is necessary to take measures to solve these psychological problems. Providing individual guidance and psychological counseling services for medical students could be beneficial.

Studies in the literature have shown that an important proportion of medical students have high levels of depression, anxiety, and stress. Making multicenter studies with the same methodology should be used to assess whether the differences in depression, anxiety, and stress rates are artificial or indeed exist. Finally, the evaluation of psychological morbidity is needed not only for students but also for other partners such as educators and parents.

\section{Financial Support}

This study was supported by the Afyon Kocatepe University Scientific Research Coordination Office with the number of "17.KARIYER.241".

\section{References}

1. Kulsoom B, Afsar NA. Stress, anxiety, and depression among medical students in a multiethnic setting. Neuropsychiatr Dis Treat 2015;11:1713-22.

2. Aktekin M, Karaman T, Senol YY, Erdem S, Erengin H, Akaydin M. Anxiety, depression and stressful life events among medical students: a prospective study in Antalya, Turkey. Med Educ 2001;35(1):12-7.

3. Iqbal S, Gupta S, Venkatarao E. Stress, anxiety \& depression among medical undergraduate students \& their socio-demographic correlates. Indian J Med Res 2015;141(3):354-7.

4. Al Saadi T, Addeen SZ, Turk T, Abbas F, Alkhatib M. Psychological distress among medical students in conflicts: a cross-sectional study from Syria. BMC Med Educ 2017;17(1):173-80.

5. Karaoğlu N, Şeker M. Anxiety and depression in medical students related to desire for and expectations from a medical career. West Indian Med J 2010;59(2):196-202.

6. Almojali AI, Almalki SA, Alothman AS, Masuadi EM, Alaqeel MK. The prevalence and association of stress with sleep quality among medical students. J Epidemiol Glob Health 2017;7(3):169-74.

7. Melaku L, Mossie A, Negash A. Stress among medical students and its association with substance use and academic performance. J Biomed Educ 2015. Doi: 10.1155/2015/149509.

8. Dahlin M, Joneborg N, Runeson B. Stress and depression among medical students: A cross-sectional study. Med Educ 2005;39(6):594-604.

9. Özdel L, Bostancı M, Özdel O, Oğuzhanoğlu NK. Üniversite öğrencilerinde depresif belirtiler ve sosyodemografik özelliklerle ilișkisi. Anadolu Psikiyatri Dergisi 2002;3(3):155-61.

10. Sherer M. Depression and suicidal ideation in college students. Psychol Rep 1985;57:1061-2.

11. Najafi Kalyani M, Jamshidi N, Salami J, Pourjam E. Investigation of the Relationship between Psychological Variables and Sleep Quality in Students of Medical Sciences. Depress Res Treat 2017; 2017:7143547.

12. Haldorsen H, Bak NH, Dissing A, Petersson B. Stress and symptoms of depression among medical students at the University of Copenhagen. Scand J Public Health 2014;42(1):89-95. 
13. Fuad MD, Al-Zurfi BM, Abdelqader MA, Bakar MF, Elnajeh M, Abdullah MR. Prevalence and risk factors of stress, anxiety and depression among medical students of a private medical university in Malaysia. Edu Med J 2016;16(3):87-92.

14. Azad N, Shahid A, Abbas N, Shaheen A, Munir N. Anxiety and depression in medical students of a private medical college. J Ayub Med Coll Abbottabad 2017;29(1):123-7.

15. Eller T, Aluoja A, Vasar V, Veldi M. Symptoms of anxiety and depression in Estonian medical students with sleep problems. Depress Anxiety 2006;23(4):250-6.

16. Dafaalla M, Farah A, Bashir S, et al. Depression, Anxiety, and Stress in Sudanese Medical Students: A Cross Sectional Study on Role of Quality of Life and Social Support. American Journal of Educational Research 2016;4(13):937-42.

17. Ergin A, Uzun SU, Bozkurt Aİ. Tıp Fakültesi Öğrencilerinin Depresyon-Anksiyete-Stres Düzeyleri ve Stresle Başa Çıkma Yöntemleri. 18. National Public Health Conference, 5-9 Sep 2015, Konya-Turkey.

18. Deniz ME, Sümer AS. The Evaluation of Depression, Anxiety and Stress in University Students with Different Self-Compassion Levels. Education and Sciences 2010;35(158):115-27.

19. Bayram N, Bilgel N. The prevalence and socio-demographic correlations of depression, anxiety and stress among a group of university students. Soc Psychiatry Psychiatr Epidemiol 2008;43(8):667-72.

20. Öncü B, Şahin T, Özdemir S, Şahin C, Çakır K, Öcal E. Tıp fakültesi öğrencilerinde depresyon, anksiyete ve stres düzeyleri ve ilişkili etmenler. Kriz Dergisi 2013;21:1-10.

21. Üstün A, Bayar A. Üniversite öğrencilerinin depresyon, anksiyete ve stres düzeylerinin çeșitli değişkenlere göre incelenmesi. Eğitim ve Öğretim Araştırmaları Dergisi 2015;4(1):384-90.

22. Odacı H, Çikrıkci Ö. Differences in Problematic Internet Use based on Depression, Anxiety, and Stress Levels. Addicta: The Turkish Journal on Addictions 2017;4:41-61.

23. Ediz B, Ozcakir A, Bilgel N. Depression and anxiety among medical students: Examining scores of the beck depression and anxiety inventory and the depression anxiety and stress scale with student characteristics. Cogent Psychol 2017;4(1);1283829.

24. Lovibond PF, Lovibond SH. The structure of negative emotional states: Comparison of the Depression Anxiety Stress Scales (DASS) with the Beck Depression and Anxiety Inventories. Behav Res Ther 1995;33(3):335-43.

25. Akin A, Çetin B. The Depression Anxiety and Stress Scale (DASS): The study of Validity and Reliability. Educ Sci Theory Pract 2007;7(1):26o-8.

26. Richards K, Techniques for measurement of sleep in critical care. Focus on Critical Care 1987;14(4):34-40.

27. Özlü ZK, Özer N. Richard-Campbell Uyku Ölçeği Geçerlilik ve Güvenilirlik Çalışması. J Turkish Sleep Medicine 2015;2:29-32.

28. Işık Ö, Özarslan A, Bekler F. Üniversite öğrencilerinde fiziksel aktivite uyku kalitesi ve depresyon ilişkisi. Niğde University Journal of Physical Education and Sport Sciences 2015;9:65-73.

29. Ngasa SN, Sama CB, Dzekem BS, et al. Prevalence and factors associated with depression among medical students in Cameroon: a cross-sectional study. BMC Psychiatry 2017; $17(1): 216-23$.

30. Ibrahim MB, Abdelreheem MH. Prevalence of anxiety and depression among medical and pharmaceutical students in Alexandria University. Alexandria Journal of Medicine 2015; 51(2):167-73.

31. Fawzy M, Hamed SA. Prevalence of psychological stress, depression and anxiety among medical students in Egypt. Psychiatry Res 2017;255:186-94.

32. Kunwar D, Risal A, Koirala S. Study of depression, anxiety and stress among the medical students in two medical colleges of Nepal. Kathmandu Univ Med J 2016;53(1):22-6.

33. Beiter R, Nash R, McCrady M, et al. The prevalence and correlates of depression, anxiety, and stress in a sample of college students. J Affect Disord 2015;173:90-6.

34. Bassols AM, Okabayashi LS, Silva ABD, et al. First-and last-year medical students: is there a difference in the prevalence and intensity of anxiety and depressive symptoms? Revista Brazilian Journal of Psychiatry 2014;36(3):233-40. 